\title{
Pathogen reduction co-benefits of nutrient best management practices
}

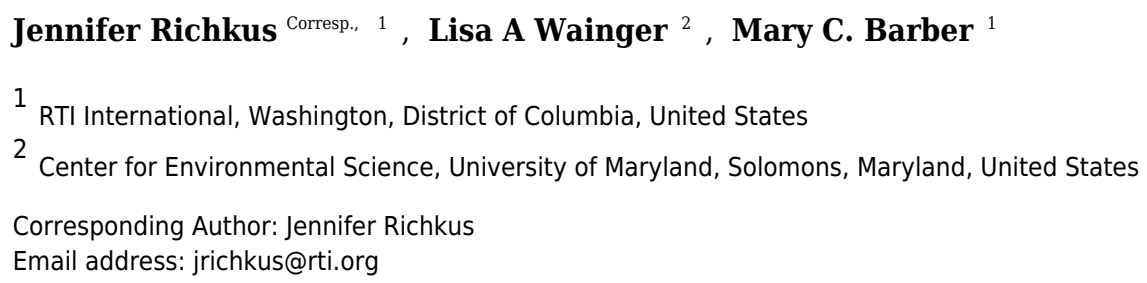

Background. Many of the practices currently underway to reduce nitrogen, phosphorus, and sediment loads entering the Chesapeake Bay have also been observed to support reduction of disease-causing pathogen loadings. We quantify how implementation of these practices, proposed to meet the nutrient and sediment caps prescribed by the Total Maximum Daily Load (TMDL), could reduce pathogen loadings and provide public health co-benefits within the Chesapeake Bay system.

Methods. We used published data on the pathogen reduction potential of management practices and baseline fecal coliform loadings estimated as part of prior modeling to estimate the reduction in pathogen loadings to the mainstem Potomac River and Chesapeake Bay attributable to practices implemented as part of the TMDL. We then compare the estimates with the baseline loadings of fecal coliform loadings to estimate the total pathogen reduction potential of the TMDL.

Results. We estimate that the TMDL practices have the potential to decrease diseasecausing pathogen loads from all point and non-point sources to the mainstem Potomac River and the entire Chesapeake Bay watershed by $19 \%$ and $27 \%$, respectively. These numbers are likely to be underestimates due to data limitations that forced us to omit some practices from analysis.

Discussion. Based on known impairments and disease incidence rates, we conclude that efforts to reduce nutrients may create substantial health co-benefits by improving the safety of water-contact recreation and seafood consumption. 


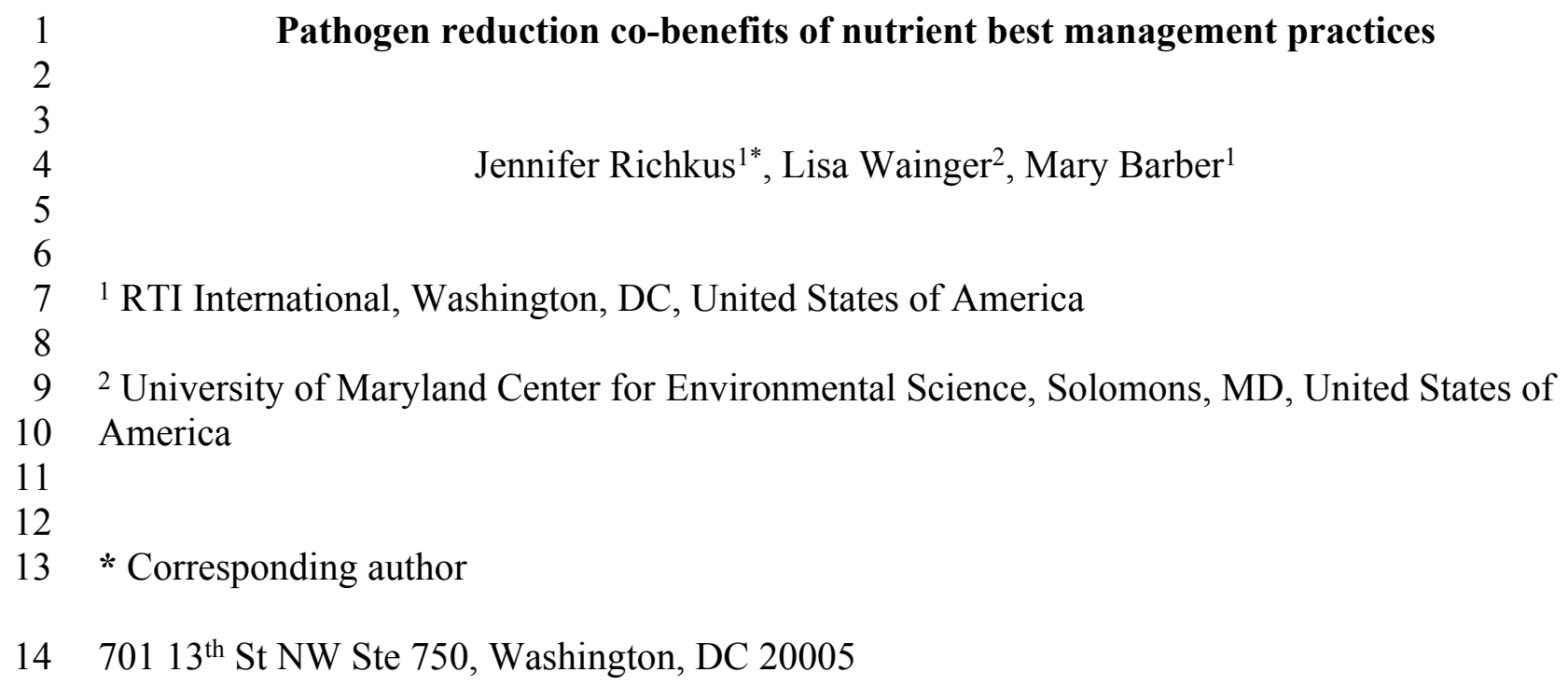




\section{Abstract}

19 Background. Many of the practices currently underway to reduce nitrogen, phosphorus,

20 and sediment loads entering the Chesapeake Bay have also been observed to support reduction of

21 disease-causing pathogen loadings. We quantify how implementation of these practices,

22 proposed to meet the nutrient and sediment caps prescribed by the Total Maximum Daily Load

23 (TMDL), could reduce pathogen loadings and provide public health co-benefits within the

24 Chesapeake Bay system.

25 Methods. We used published data on the pathogen reduction potential of management

26 practices and baseline fecal coliform loadings estimated as part of prior modeling to estimate the

27 reduction in pathogen loadings to the mainstem Potomac River and Chesapeake Bay attributable

28 to practices implemented as part of the TMDL. We then compare the estimates with the baseline

29 loadings of fecal coliform loadings to estimate the total pathogen reduction potential of the

30 TMDL.

31 Results. We estimate that the TMDL practices have the potential to decrease disease-

32 causing pathogen loads from all point and non-point sources to the mainstem Potomac River and

33 the entire Chesapeake Bay watershed by $19 \%$ and $27 \%$, respectively. These numbers are likely to

34 be underestimates due to data limitations that forced us to omit some practices from analysis.

35 Discussion. Based on known impairments and disease incidence rates, we conclude that

36 efforts to reduce nutrients may create substantial health co-benefits by improving the safety of

37 water-contact recreation and seafood consumption.

38

39

40

\section{Introduction}

Chesapeake Bay water quality has diminished over the past 60 years to the point that the system is less able to support abundant crabs and diverse fish, feed waterfowl, and produce safe 
41 recreational opportunities. To restore the bay, the U.S. Environmental Protection Agency (EPA)

42 Chesapeake Bay Total Maximum Daily Load (TMDL) has been developed, which sets yearly

43 caps on the levels of nitrogen, phosphorus, and sediment entering the system. Jurisdictions in the

44 watershed (Delaware, Maryland, New York, Pennsylvania, Virginia, West Virginia and the

45 District of Columbia) have created Watershed Implementation Plans (WIPs) to meet the

46 requirements of the TMDL. The WIPs (Phase 2) include a diverse list of best management

47 practices (BMPs) that impede the interaction and/or delivery of nutrients and sediment

48 downstream, many of which also have the potential to reduce pathogens through this mechanism

49 (Mallin, Williams et al. 2000, Knox, Dahlgren et al. 2008).

50 Water that interacts with fecal matter can contain diverse pathogens such as Vibrio, E.

51 coli (pathogenic), Shigella, Rotavirus, Yersinia, Cryptosporidium, and Giardia (Savichtcheva

52 and Okabe 2006) that have been linked to gastrointestinal illnesses, skin infections, fevers, and

53 other human health concerns (Vann, Mandel et al. 2002). Limited data are available on pathogen

54 concentrations and exposure in the watersheds we studied; however, the level of concern for

55 pathogens in the Chesapeake Bay watershed is evident from the actions that officials have taken

56 to address them. Because of the potential for creating illness, government officials have

57 responded to potential water contamination by closing beaches and waterways to recreators and

58 closing shellfish beds to commercial and recreational harvest. For example, 176 Virginia

59 shellfishing areas are indefinitely closed due to elevated fecal coliform (VDH 2012, EPA 2013,

60 February 11), and 77 shellfish beds are occasionally or permanently closed in Maryland (MDE

61 2016). As recently as 2008, approximately 8\% of all shellfish beds in Maryland and Virginia

62 were estimated to be closed due the potential for pathogen-related illness. These areas represent a 
63 cumulative impact to an industry valued at approximately \$13 million in Maryland and Virginia

64 in 2008 (Pelton and Goldsborough 2010).

65 This study utilizes the data available in the literature and simple estimations to

66 demonstrate that measurable reductions to pathogen loadings in the Chesapeake Bay are likely,

67 as a result of implementing the TMDL. These reductions, in turn, can provide benefits to

68 recreators and fishers by increasing confidence in waters and potentially reducing closures, and

69 to government officials by reducing the level of effort expended on pathogen-related actions.

70 Although more research will be needed to quantify and value the change, this study is

71 intended to indicate the ancillary benefits that can be considered by decision makers when

72 weighing the costs and benefits of environmental management programs such as TMDLs.

\section{Materials and Methods}

74 This analysis investigated the effects of the WIPs by examining the effectiveness of

75 practices for reducing pathogen delivery to waterways. Information on current pathogen loadings

76 in the Potomac River basin and pathogen reduction potential of BMPs was gathered to estimate

77 the potential reduction in pathogens throughout the Potomac River basin and the Chesapeake

78 Bay watershed (Figure 1). 


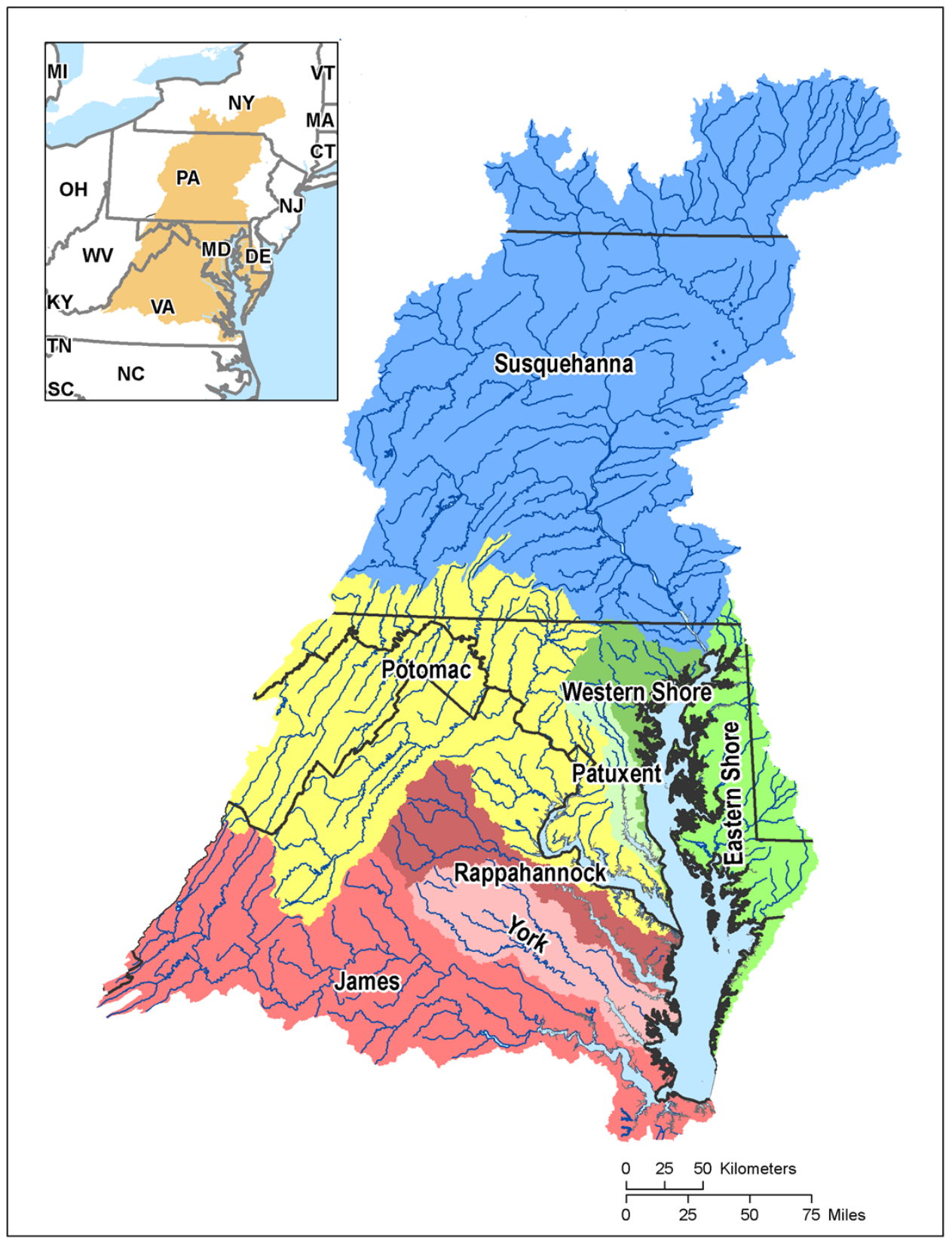

\section{Figure 1. Map of the Chesapeake Bay Watershed and Tributary Basins}

81 Four steps were applied to estimate the potential pathogen reduction attributable to the TMDL,

82 as described below. 


\section{Step 1: Define BMPs in Chesapeake Bay TMDL Implementation}

To define the types and extent of BMP implementation proposed to meet the TMDL, we used information generated by Chesapeake Bay Watershed Model scenarios developed for and run by the US EPA Chesapeake Bay Program. The scenarios are based on the Phase 2 WIPs provided by all of the Chesapeake Bay jurisdictions to EPA and indicate acreage or number of BMPs that are anticipated to be implemented within given areas of the watershed. Using the information provided by US EPA Chesapeake Bay Program, we calculated the difference in estimates between the "2009 baseline" and the "with TMDL" model run scenarios. Thus, our estimates of BMP implementation represent the change in pathogen loads resulting only from actions taken to meet the TMDL.

\section{Step 2: Identify Pathogen Reduction Efficiencies for BMPs}

We then conducted a literature review of the BMPs identified in the Chesapeake Bay WIPs to investigate the potential efficiency of agricultural, urban, and septic BMPs in reducing pathogens at edge of field or edge of (small) streams. The WIP efforts identified to have the potential to affect the delivery and concentration of these waterborne pathogens include (categorized by source):

1. Agricultural: pasture and grazing management, nutrient management on crop fields, livestock waste management, restricted stream access, plantings and other structural practices to reduce nutrient and sediment runoff.

2. Urban: detention and retention ponds, impervious surface reduction, street sweeping, forested riparian buffers, bioswales, afforestation.

3. Septic: connecting septic systems to sewers, septic pumping, and on-site septic upgrades. 
4. Wastewater treatment plants: new and enhanced treatment of municipal waste.

The literature review was conducted by employing each of the BMPs and pathogenrelated terms as keywords (e.g., "restricted stream access" or "riparian buffer" and "fecal coliform" or "E. coli” or "bacteria") using Google Scholar, EBSCO, and Google as search engines. Pathogen reduction estimates from peer-reviewed journal articles, documentation

111 prepared by state agencies for compliance with TMDLs, and best practice guidance reports from 112 state agencies and universities were all considered for the purposes of this paper. Data were

113 included in the analysis only if they could be matched to the BMP form and function and were

114 relevant to the pathogens being evaluated.

115 The range of pathogen removal efficiencies varied widely from $-6 \%$ to $99 \%$, where

116 negative efficiencies increased pathogen concentrations as a result of the BMP implementation

117 (Table 1). It was observed that fecal indicator bacteria (FIB), which includes fecal coliform and

118 E. coli, were most often evaluated as a surrogate for a variety of pathogens (Marion, Lee et al.

119 2010, EPA 2012). Therefore, to make the best use of the literature, we averaged the efficiencies

120 of fecal coliform and E. coli into a single FIB value to associate with each BMP in the analysis.

121 Table 1. Literature Review of Pathogen Reduction Efficiencies for Crop, Pasture, Urban, 122 and Septic BMPs.

\begin{tabular}{|c|c|c|c|}
\hline $\begin{array}{c}\text { Best Management } \\
\text { Practice }^{\mathrm{a}}\end{array}$ & $\begin{array}{c}\text { Loading Reduction } \\
\text { Efficiency }(\%)\end{array}$ & $\begin{array}{c}\text { Average } \\
\text { Fecal } \\
\text { Coliform } \\
\text { and } E \text {. Coli } \\
\text { (FIB) } \\
\text { Efficiency } \\
(\%) \\
\end{array}$ & Reference \\
\hline \multicolumn{4}{|l|}{ Crop Practices } \\
\hline Forest Buffers & $\begin{array}{l}\text { Fecal coliform: } 43 \%- \\
57 \%\end{array}$ & $50 \%$ & $\begin{array}{l}\text { (Virginia Department } \\
\text { of Environmental } \\
\text { Quality 2003) }\end{array}$ \\
\hline
\end{tabular}




\begin{tabular}{|c|c|c|c|}
\hline $\begin{array}{l}\text { Best Management } \\
\text { Practice }^{\mathrm{a}}\end{array}$ & $\begin{array}{c}\text { Loading Reduction } \\
\text { Efficiency }(\%)\end{array}$ & $\begin{array}{c}\text { Average } \\
\text { Fecal } \\
\text { Coliform } \\
\text { and } E \text {. Coli } \\
(\text { FIB })^{\mathbf{b}} \\
\text { Efficiency } \\
(\%)\end{array}$ & Reference \\
\hline Grass Buffers & $\begin{array}{l}\text { E. coli: } 58 \%-99 \% \\
\text { Fecal coliform: } 28 \%- \\
100 \%\end{array}$ & $71 \%$ & $\begin{array}{l}\text { (Minnesota Pollution } \\
\text { Control Agency } \\
\text { 2009); (Peterson, } \\
\text { Jordan et al. 2012) }\end{array}$ \\
\hline Land Retirement & $90 \%-93 \%$ & $92 \%$ & $\begin{array}{l}\text { (Virginia Department } \\
\text { of Environmental } \\
\text { Quality 2003); } \\
\text { (Peterson, Jordan et al. } \\
\text { 2012) }\end{array}$ \\
\hline Water Control Structures & $\begin{array}{l}\text { Detention structures: } \\
67 \%\end{array}$ & $67 \%$ & $\begin{array}{l}\text { (Leisenring, Clary et } \\
\text { al. 2012) }\end{array}$ \\
\hline Wetland Restoration & $\begin{array}{l}\text { E. coli: } 40 \% \\
\text { Fecal coliform: } 30 \%\end{array}$ & $35 \%$ & $\begin{array}{l}\text { (Virginia Department } \\
\text { of Environmental } \\
\text { Quality 2003) }\end{array}$ \\
\hline $\begin{array}{l}\text { Non-urban Stream } \\
\text { Reduction }\end{array}$ & No estimate & Not included & \\
\hline \multicolumn{4}{|l|}{ Pasture Practices } \\
\hline Barnyard Runoff Control & Fecal coliform: $81 \%$ & $81 \%$ & \\
\hline Forest Buffers & $\begin{array}{l}\text { Fecal coliform: } 43 \%- \\
57 \%\end{array}$ & $50 \%$ & $\begin{array}{l}\text { (Virginia Department } \\
\text { of Environmental } \\
\text { Quality 2003) }\end{array}$ \\
\hline Grass Buffers & $\begin{array}{l}\text { E. coli: } 58 \%-99 \% \\
\text { Fecal coliform: } 28 \% \text { - } \\
100 \%\end{array}$ & $71 \%$ & $\begin{array}{l}\text { (Minnesota Pollution } \\
\text { Control Agency } \\
\text { 2009); (Peterson, } \\
\text { Jordan et al. 2012) }\end{array}$ \\
\hline $\begin{array}{l}\text { Horse Pasture } \\
\text { Management }\end{array}$ & E. coli: $72 \%$ & $72 \%$ & $\begin{array}{l}\text { (Peterson, Cavinder et } \\
\text { al. 2012) }\end{array}$ \\
\hline Loafing Lot Management & Fecal coliform: $50 \%$ & $50 \%$ & $\begin{array}{l}\text { (Virginia Department } \\
\text { of Environmental } \\
\text { Quality 2003) }\end{array}$ \\
\hline $\begin{array}{l}\text { Pasture Alternative } \\
\text { Watering }\end{array}$ & $\begin{array}{l}\text { E. coli: } 85 \%-95 \% \\
\text { Fecal coliform: } 51 \% \text { - } \\
94 \%\end{array}$ & $82 \%$ & $\begin{array}{l}\text { (Sheffield, } \\
\text { Mostaghimi et al. } \\
\text { 1997); (Byers, Cabrera } \\
\text { et al. 2005) }\end{array}$ \\
\hline $\begin{array}{l}\text { Precision Intensive } \\
\text { Rotational Grazing }\end{array}$ & Fecal coliform: $90 \%$ & $90 \%$ & $\begin{array}{l}\text { (Minnesota Pollution } \\
\text { Control Agency 2009) }\end{array}$ \\
\hline Prescribed Grazing & $\begin{array}{l}\text { E. coli: } 66 \%-72 \% \\
\text { Fecal coliform: } 90 \%- \\
96 \%\end{array}$ & $80 \%$ & $\begin{array}{l}\text { (Peterson, Redmon et } \\
\text { al. 2011) }\end{array}$ \\
\hline
\end{tabular}




\begin{tabular}{|c|c|c|c|}
\hline $\begin{array}{c}\text { Best Management } \\
\text { Practice }^{\mathrm{a}}\end{array}$ & $\begin{array}{l}\text { Loading Reduction } \\
\text { Efficiency (\%) }\end{array}$ & $\begin{array}{c}\text { Average } \\
\text { Fecal } \\
\text { Coliform } \\
\text { and } E \text {. Coli } \\
(\text { FIB })^{\mathbf{b}} \\
\text { Efficiency } \\
(\%)\end{array}$ & Reference \\
\hline $\begin{array}{l}\text { Stream Access Control } \\
\text { with Fencing }\end{array}$ & $\begin{array}{l}\text { E. coli: } 37 \%-46 \% \\
\text { Fecal coliform: } 30 \%- \\
94 \%\end{array}$ & $52 \%$ & $\begin{array}{l}\text { (Schaetzle 2005, July } \\
\text { 28); (Peterson, } \\
\text { Redmon et al. 2011) }\end{array}$ \\
\hline $\begin{array}{l}\text { Ammonia Emission } \\
\text { Reductions }\end{array}$ & No estimate & Not included & \\
\hline $\begin{array}{l}\text { Conservation Tillage with } \\
\text { Continuous No Till }\end{array}$ & $\begin{array}{l}\text { No estimate: heavily } \\
\text { dependent on if and } \\
\text { when animal manure } \\
\text { has been applied }\end{array}$ & Not included & $\begin{array}{l}\text { (Ramirez, Wang et al. } \\
\text { 2009) }\end{array}$ \\
\hline Dairy Precision Feeding & No estimate & Not included & \\
\hline $\begin{array}{l}\text { Livestock Mortality } \\
\text { Composting }\end{array}$ & No estimate & Not included & \\
\hline $\begin{array}{l}\text { Livestock Waste } \\
\text { Management Systems }\end{array}$ & $\begin{array}{l}\text { E. coli: } 97 \%-99 \% \\
\text { Fecal coliform: } 44 \%- \\
99 \%\end{array}$ & Not included & $\begin{array}{l}\text { (Virginia Department } \\
\text { of Environmental } \\
\text { Quality 2003); } \\
\text { (Redmon, Wagner et } \\
\text { al. 2012); }\end{array}$ \\
\hline $\begin{array}{l}\text { Manure Transport Inside } \\
\text { CBWS }\end{array}$ & No estimate & Not included & \\
\hline $\begin{array}{l}\text { Manure Transport } \\
\text { Outside CBWS }\end{array}$ & Assumed to be $99 \%$ & Not included & \\
\hline $\begin{array}{l}\text { Non-urban Stream } \\
\text { Restoration }\end{array}$ & Fecal coliform: $30 \%$ & Not included & $\begin{array}{l}\text { (Virginia Department } \\
\text { of Environmental } \\
\text { Quality 2003) }\end{array}$ \\
\hline Poultry Phytase & No estimate & Not included & \\
\hline $\begin{array}{l}\text { Poultry Waste } \\
\text { Management Systems }\end{array}$ & $\begin{array}{l}\text { Fecal coliform: } 75 \% \\
\text { E. coli: } 96 \%\end{array}$ & Not included & $\begin{array}{l}\text { (Virginia Department } \\
\text { of Environmental } \\
\text { Quality 2003); } \\
\text { (Redmon, Wagner et } \\
\text { al. 2012) }\end{array}$ \\
\hline \multicolumn{4}{|l|}{ Urban Practices } \\
\hline BioRetention & E. coli: $71 \%$ & $71 \%$ & $\begin{array}{l}\text { (Leisenring, Clary et } \\
\text { al. 2012) }\end{array}$ \\
\hline Bioswale & $\begin{array}{l}\text { Fecal coliform: }-5 \%^{\mathrm{c}} \\
\text { E. coli: }-6 \%\end{array}$ & $-6 \%$ & $\begin{array}{l}\text { (Leisenring, Clary et } \\
\text { al. 2012) }\end{array}$ \\
\hline Dry Ponds & Fecal coliform: $80 \%$ & $80 \%$ & $\begin{array}{l}\text { (Tilman, Plevan et al. } \\
\text { 2011) }\end{array}$ \\
\hline
\end{tabular}




\begin{tabular}{|c|c|c|c|}
\hline $\begin{array}{c}\text { Best Management } \\
\text { Practice }^{\mathrm{a}}\end{array}$ & $\begin{array}{l}\text { Loading Reduction } \\
\text { Efficiency (\%) }\end{array}$ & $\begin{array}{c}\text { Average } \\
\text { Fecal } \\
\text { Coliform } \\
\text { and } E \text {. Coli } \\
(\text { FIB })^{\mathbf{b}} \\
\text { Efficiency } \\
(\%)\end{array}$ & Reference \\
\hline $\begin{array}{l}\text { Erosion and Sediment } \\
\text { Control }\end{array}$ & $\begin{array}{l}\text { Assumed average of all } \\
\text { urban stormwater } \\
\text { practices: } \\
\text { Fecal coliform: } 53 \% \\
\text { E. coli: } 60 \%\end{array}$ & $57 \%$ & \\
\hline Filtering Practices & $\begin{array}{l}\text { Fecal coliform: } 60 \% \\
\text { E. coli: } 99 \%\end{array}$ & $80 \%$ & $\begin{array}{l}\text { (Clary, Jones et al. } \\
\text { 2008) }\end{array}$ \\
\hline Forest Buffers & $\begin{array}{l}\text { Fecal coliform: } 43 \%- \\
57 \%\end{array}$ & $50 \%$ & $\begin{array}{l}\text { (Virginia Department } \\
\text { of Environmental } \\
\text { Quality 2003) }\end{array}$ \\
\hline $\begin{array}{l}\text { Impervious Surface } \\
\text { Reduction }\end{array}$ & $\begin{array}{l}\text { Assumed average of all } \\
\text { urban stormwater } \\
\text { practices: } \\
\text { Fecal coliform: } 53 \% \\
\text { E. coli: } 60 \%\end{array}$ & $57 \%$ & \\
\hline Infiltration Practices & $\begin{array}{l}\text { Assumed to be } \\
\text { equivalent to Leisenring } \\
\text { et al. (Leisenring, Clary } \\
\text { et al. } 2012 \text { ) retention } \\
\text { ponds: } \\
\text { E. coli: } 95 \% \\
\text { Fecal coliform: } 65 \%\end{array}$ & $80 \%$ & $\begin{array}{l}\text { (Leisenring, Clary et } \\
\text { al. 2012) }\end{array}$ \\
\hline $\begin{array}{l}\text { Retrofit Stormwater } \\
\text { Management }\end{array}$ & $\begin{array}{l}\text { Assumed average of all } \\
\text { urban stormwater } \\
\text { practices: } \\
\text { Fecal coliform: } 53 \% \\
\text { E. coli: } 60 \%\end{array}$ & $57 \%$ & \\
\hline Wet Ponds \& Wetlands & $\begin{array}{l}\text { Fecal coliform: } 53 \% \\
\text { E. coli: } 43-68 \%\end{array}$ & $48 \%$ & $\begin{array}{l}\text { (Leisenring, Clary et } \\
\text { al. 2012); (Knox, } \\
\text { Dahlgren et al. 2008) }\end{array}$ \\
\hline $\begin{array}{l}\text { Abandoned Mine } \\
\text { Reclamation }\end{array}$ & No estimate & Not included & \\
\hline Street Sweeping & $\begin{array}{l}\text { Fecal coliform: } 1.4 \%- \\
4.3 \%\end{array}$ & Not included & $\begin{array}{l}\text { (Zarriello, Breault et } \\
\text { al. 2003) }\end{array}$ \\
\hline Tree Planting & No estimate & Not included & \\
\hline Urban Stream Restoration & No estimate & Not included & \\
\hline \multicolumn{4}{|l|}{ Septic Practices } \\
\hline $\begin{array}{l}\text { Combined Sewer } \\
\text { Overflow Elimination }\end{array}$ & Fecal coliform: 99\% & Not included & $\begin{array}{l}\text { (City of Grand Rapids } \\
\text { 2011) }\end{array}$ \\
\hline
\end{tabular}




\begin{tabular}{|c|c|c|c|}
\hline $\begin{array}{l}\text { Best Management } \\
\text { Practice }^{\mathrm{a}}\end{array}$ & $\begin{array}{c}\text { Loading Reduction } \\
\text { Efficiency }(\%)\end{array}$ & $\begin{array}{c}\text { Average } \\
\text { Fecal } \\
\text { Coliform } \\
\text { and } E \text {. Coli } \\
\text { (FIB) }^{\mathbf{b}} \\
\text { Efficiency } \\
(\%)\end{array}$ & Reference \\
\hline Septic Connections & Fecal coliform: $99 \%$ & Not included & $\begin{array}{l}\text { (Vann, Mandel et al. } \\
\text { 2002); (Petersen, Rifai } \\
\text { et al. 2009) }\end{array}$ \\
\hline Septic Denitrification & No estimate obtained & Not included & \\
\hline Septic Pumping & Fecal coliform: $5 \%$ & Not included & $\begin{array}{l}\text { (Virginia Department } \\
\text { of Environmental } \\
\text { Quality 2003) }\end{array}$ \\
\hline Treatment Plant Upgrades & $\begin{array}{l}\text { No estimate: heavily } \\
\text { dependent on type of } \\
\text { upgrade and technology } \\
\text { implemented }\end{array}$ & Not included & \\
\hline
\end{tabular}

${ }^{a}$ No comprehensive set of definitions of the BMPs used in the WIPs was available; however, definitions for these agricultural practices agricultural practices can be found here: http://mda.maryland.gov/resource conservation/WIPCountyDocs/bmpdef pg.pdf. Summaries of the types of practices used in the urban BMPs can be found here: http://www.dnrec.delaware.gov/swc/wa/Documents/ChesapeakePhaseIIWIP/Final Phase2_CB WIP 03302012A.pdf.

${ }^{b}$ FIB, or fecal indicator bacteria, reduction efficiency is represented by the average reduction efficiencies of $E$. coli and fecal coliform for the purposes of this analysis.

${ }^{c}$ Negative removal efficiencies indicate that the concentrations of pathogens increased as a result of the BMP implementation.

Agricultural practices showed a range of efficiencies at removing fecal coliform and $E$.

except wetland and stream restoration. Studies also showed high efficiency of grassed buffers at removing cryptosporidium (93\%-99\%). Stormwater practices showed a wider range of removal efficiencies (-6\%-99\%) than agricultural practices when looking across the range of practices. However, a few practices were responsible for the cases of low performance (bioswales, street sweeping, and septic pumping). The majority of practices had average efficiencies of $48 \%$ or greater. 


\section{Step 3: Estimate Baseline Pathogen Loads}

142 To estimate the baseline pathogen load, we required an understanding of pathogen

143 sources and deliveries to water bodies, for the given level of management practices implemented

144 in the baseline scenario. A study of the Upper Potomac River Basin, the portion that lies above

145 the fall line, ${ }^{*}$ provided the best available information about how pathogens were being produced,

146 transformed, intercepted and, finally, delivered downstream (Vann, Mandel et al. 2002). That

147 study estimated average annual edge-of-stream pathogen loadings for a period that roughly

148 corresponded to 2000 to 2010 . The 2010 scenario was a projection of land use and population

149 changes expected to occur by 2010 combined with 2000 estimates of non-point source BMPs and

150 wastewater loads, and 2010 estimates for septic conditions. We use the 2010 model results as if

151 they occurred in conditions equivalent to the baseline scenario developed by the Chesapeake Bay

152 Program (CBP).

$153 \quad$ Vann et al. (2002) estimated loadings by land use type, using models similar to those of

154 the CBP but modified to include pathogen movement and transformation and a wide variety of

155 data sources on fecal sources. Data on livestock, geese, deer and human populations; National

156 Pollution Discharge Elimination System (NPDES) and wastewater emissions; and other sources

157 were used to inform modeling of pathogen loads by land use type. The CBP watershed model

158 was adapted to include bacterial fate and transport, and the loads by land use were calibrated

159 using pathogen concentrations measured at monitoring stations, primarily within the main

160 channel of this major Chesapeake tributary. The model was also combined with data from

161 surface water intakes to estimate the downstream delivery factors for the Potomac River basin.

\footnotetext{
* The fall line in the Chesapeake Bay watershed is a geomorphic feature marked by a steep drop in elevation that occurs where the Piedmont and Coastal Plain geophysical provinces meet. It roughly corresponds to the division between non-tidal waters (above) and tidal waters (below).
} 

entire Potomac River basin and the Chesapeake Bay watershed, we converted the edge-of-stream

164 loads to per acre loadings per land use type (Table 2). We evaluated only the three land uses

165 being modified by the BMPs used in the analysis for the purposes of converting edge-of-stream

166 loads, as described below. We then multiplied the per acre loads for acreages of pasture,

167 cropland, and urban for the baseline scenario to estimate baseline loads. to two different scales of analysis (Potomac River and entire Chesapeake Bay watersheds), to

170 provide a rough estimate of TMDL implementation effects at these scales. Clearly, using data

171 from a portion of the Potomac River basin to represent either the whole Potomac River basin or

172 the entire Chesapeake Bay watershed requires making considerable assumptions about the

173 similarity of patterns and processes at these two scales. We have greater confidence in the

174 Potomac River basin results because the Potomac River basin would be expected to be more

175 similar to the originally modeled area than the Chesapeake Bay as a whole. The Potomac River

176 basin may be a reasonable model for the entire Chesapeake Bay watershed because it makes up

177 over one-fifth of the Chesapeake Bay watershed and has proportions and distribution of land use

178 types that are similar to the entire Chesapeake Bay watershed. However, the Potomac River

179 basin differs from the Chesapeake Bay watershed in that it has slightly more urban land and 180 pasture and less forest (Table 3), and BMPs were applied in different proportions to the whole

181 Bay, as shown in the Results and Discussion section.

182 Table 2. Modeled Loadings per Land Use Source in the Upper Potomac River Basin.

\begin{tabular}{|c|c|c|c|}
\hline $\begin{array}{c}\text { Loading } \\
\text { Type/Land } \\
\text { Use }\end{array}$ & $\begin{array}{c}\text { Edge-of-Stream } \\
\text { Delivery of Fecal } \\
\text { Coliform (cfu/yr) }\end{array}$ & $\begin{array}{c}\text { Edge-of-Stream } \\
\text { Delivery per Acre } \\
\text { (cfu/ac/yr) }\end{array}$ & $\begin{array}{c}\text { Edge-of-Stream } \\
\text { Loading Delivered } \\
\text { Downstream (\%) }\end{array}$ \\
\hline Cropland & $6.0 \mathrm{E}+16$ & $5.18 \mathrm{E}+10$ & $25 \%$ \\
\hline
\end{tabular}




\begin{tabular}{|l|l|l|l|}
\hline Pasture & $3.2 \mathrm{E}+17$ & $3.88 \mathrm{E}+11^{\mathrm{c}}$ & $28 \%$ \\
\hline Feedlots & $6.3 \mathrm{E}+16$ & $3.88 \mathrm{E}+11^{\mathrm{c}}$ & $24 \%$ \\
\hline Cattle & $1.0 \mathrm{E}+16$ & & $21 \%$ \\
\hline Urban & $2.2 \mathrm{E}+16$ & $1.82 \mathrm{E}+10$ & $27 \%$ \\
\hline
\end{tabular}

183 All data derived from Vann et al. (2002)

184 a Pathogens were measured as fecal coliform in colony forming units per year (cfu/year).

185 b Proportion delivered downstream was calculated with mass balance equations, based on data

186 provided by Vann et al. (2002).

$187^{\mathrm{c}}$ Land uses were combined for the delivery estimates per acre because acreages were not

188 reported separately for these land uses.

189 d Cattle land use is an estimate of deposition of feces directly into water bodies.

190

191 Table 3. Land Use Composition of Potomac River Basin and the Chesapeake Bay

192 Watershed.

\begin{tabular}{|l|l|l|l|l|}
\hline \multicolumn{1}{|c|}{ Land Use } & $\begin{array}{c}\text { Potomac River } \\
\text { Basin (acres) }\end{array}$ & $\begin{array}{c}\text { Potomac River } \\
\text { Basin Land Use (\%) }\end{array}$ & $\begin{array}{c}\text { Chesapeake } \\
\text { Bay Land Use } \\
\text { (acres) }\end{array}$ & $\begin{array}{c}\text { Chesapeake } \\
\text { Bay Basin } \\
\text { Land Use (\%) }\end{array}$ \\
\hline Forest & $5,189,905$ & $59 \%$ & $26,512,720$ & $65 \%$ \\
\hline Cropland & $1,405,191$ & $16 \%$ & $6,640,633$ & $16 \%$ \\
\hline Pasture & 920,935 & $10 \%$ & $2,438,478$ & $6 \%$ \\
\hline Urban & $1,245,535$ & $14 \%$ & $4,853,216$ & $12 \%$ \\
\hline Other & 99,827 & $1 \%$ & 653,219 & $2 \%$ \\
\hline Total & $8,861,392$ & $\begin{array}{l}100 \%(22 \% \text { of } \\
\text { Chesapeake Bay } \\
\text { watershed) }\end{array}$ & $41,098,267$ & $100 \%$ \\
\hline
\end{tabular}

193 Data source: Jeff Sweeney of the US EPA Chesapeake Bay Program; 2009 baseline scenario data

\section{Step 4: Estimate change in pathogens due to the TMDL}

As described earlier, the acreage of BMPs implemented due to the TMDL was derived by

subtracting the baseline BMP implementation from the "with TMDL" scenario. Each BMP was

associated with a particular land use and quantified in terms of the acres of that land use that

were affected by implementation of the BMP. For example, prescribed grazing was associated

200 changes in pathogen loads. 
202 loads were used in our analysis. BMPs were omitted from analysis if they were not measured in

203 terms of acreage in the state WIPs, or if efficiencies were specific to baseline conditions that

204 could not be accurately measured. For example, omitted BMPs include those measured as

205 pounds of manure transported outside of the watershed and miles of stream restored. Also, some

206 cropland practices in widespread use, such as continuous no-till, can be effective at reducing

207 pathogens, but only when applied to cropland receiving manure; lack of sufficient data on

manure handling prevented their inclusion. Omitting these practices, as well as point source

practices, such as septic and wastewater treatment plant upgrades, tends to make our study more

conservative in terms of the TMDL effectiveness for reducing pathogens because practices that

are expected to be implemented as part of the WIPs were not counted, and some of these

practices have been demonstrated to be highly effective at reducing pathogen loads (Table 1).

To estimate the change in pathogen loads (measured as FIB) delivered to the main

channel as a result of applying a subset of BMPs from the WIPs, we applied Equation 1:

$$
\Delta F I B_{D S}=\sum_{l}\left(\sum_{b} \frac{(\text { BMP Acres })_{b, l}}{(\text { Total land area })_{l}}(\% F I B \text { reduction })_{b}\right)(\text { EOS load })_{l}(\% \text { DS Delivery })_{l}
$$

215 where

$b$ is the BMP applied and

I is the land use type.

Equation 1 shows that delivery of pathogens to the main channel depends on edge-of-

219 stream (EOS) loads and downstream (DS) attenuation of pathogen loads.

land area per land use $(l)$ was derived from the baseline scenario. The $\% F I B$ reduction was the 
223 treated acres to total acres in a given land use was multiplied by the percentage reduction for a

224 given practice, and then these values were summed for all BMPs affecting a land use to generate

225 a weighted sum representing the percentage reduction in pathogen loads expected for a given

226 land use. The expected percent reduction for a given land use was multiplied by the baseline load

227 for that land use to generate the EOS load (cfu/yr). Finally, the DS load was estimated by

228 multiplying the EOS load by $21 \%$, which was the average delivery ratio for all Potomac River

229 segments modeled in the study by Vann et al. (2002).

230 Results and Discussion

231 Using the subset of BMPs that we were able to include, we estimated that the

232 downstream pathogen reductions in the Potomac River Basin due to WIP implementation would

233 be on the order of $19 \%$ and in the Chesapeake Bay on the order of $27 \%$ total reduction. In the

234 Potomac, $23 \%$ of reductions were derived from pasture loads, $6 \%$ from cropland loads, and $7 \%$

235 from urban loads (excluding point source loads) (Table 4). The 19\% pathogen load reduction

236 (downstream delivery) is estimated relative to total loads from all point and non-point sources to

237 the mainstem Potomac River Basin including domestic and wild animal sources. Urban load

238 reduction results are sensitive to assumptions that practices will be maintained.

239 Table 4. Total Loading Reduction Estimates for the Potomac River Basin and Chesapeake

$240 \quad$ Bay Watershed ${ }^{\mathrm{a}}$.

\begin{tabular}{|l|l|l|l|l|}
\hline & \multicolumn{1}{|c|}{$\begin{array}{c}\text { Pasture } \\
\text { Practices } \\
\text { Reduction } \\
\text { (pasture }+ \\
\text { feedlots) }\end{array}$} & $\begin{array}{c}\text { Crop } \\
\text { Practices } \\
\text { Reduction }\end{array}$ & $\begin{array}{c}\text { Urban } \\
\text { Practices } \\
\text { Reduction }\end{array}$ & \multicolumn{1}{|c|}{$\begin{array}{c}\text { Total (all } \\
\text { sources) }\end{array}$} \\
\hline Potomac River Basin & \multicolumn{5}{|l}{} \\
\hline Acres of BMPs & 273,423 & 136,341 & 114,676 & 524,440 \\
\hline $\begin{array}{l}\text { Potential reduction main } \\
\text { channel (cfu/yr) }\end{array}$ & $1.73 \mathrm{E}+16$ & $9.80 \mathrm{E}+14$ & $3.44 \mathrm{E}+14$ & $1.86 \mathrm{E}+16$ \\
\hline
\end{tabular}




\begin{tabular}{|l|l|l|l|l|}
\hline $\begin{array}{l}\text { Sector loadings reduced } \\
(\%)\end{array}$ & $23 \%$ & $6 \%$ & $7 \%$ & $\mathbf{1 9 \%}$ \\
\hline Chesapeake Bay Watershed & $1,098,666$ & 820,429 & $1,071,777$ & $2,990,872$ \\
\hline Acres of BMPs & $7.28 \mathrm{E}+16$ & $6.25 \mathrm{E}+15$ & $3.21 \mathrm{E}+15$ & $8.22 \mathrm{E}+16$ \\
\hline $\begin{array}{l}\text { Potential reduction main } \\
\text { channel (cfu/yr) }\end{array}$ & $8 \%$ & $17 \%$ & $\mathbf{2 7 \%}$ \\
\hline $\begin{array}{l}\text { Sector loadings reduced } \\
(\%)\end{array}$ & $36 \%$ & $8 \%$ & & \\
\hline
\end{tabular}

a The percentage of total load reduction is calculated as the expected reduction in load from agriculture and urban non-point source sectors divided by estimated pathogen loads from all watershed sources (including wildlife and point sources). Therefore, the total in the rightmost column is smaller than the weighted sum of the percentage reductions from the three individual source sectors shown in the other columns.

Percentage reductions are higher for the entire Chesapeake Bay watershed due to the

247 increased agricultural land use composition, where the most potential for pathogen reduction was

248 identified and able to be included in the analysis. The $27 \%$ total reduction in pathogen loads to

249 the Bay tidal waters were from $36 \%$ reduction from pasture loads, $8 \%$ from cropland loads, and

$25017 \%$ of urban loads (excluding point source loads) (Table 4). However, we expect these numbers

251 to be underestimates of the mainstem effects because the analysis does not include effects of

252 septic upgrades, combined sewer overflows eliminations and some BMPs that were omitted but

253 that are known to have high efficiency at removing pathogens.

254 The exclusion of BMPs, such as the waste management systems and septic connections,

255 are a source of underestimation. For example, analyses developed for bacterial TMDLs in

256 Virginia (Virginia Department of Environmental Quality 2011) estimated that the elimination of

257 emissions from 46 failing septic systems in Sugarland Run would reduce E. coli instream

258 loadings by $8.89 \times 10^{11} \mathrm{cfu} / \mathrm{yr}$, which is an estimated per unit loading of $1.93 \times 10^{10} \mathrm{cfu} / \mathrm{yr}$

259 (Virginia Department of Environmental Quality 2011). If, based on the literature review, we 
260 assume $1.93 \times 10^{10} \mathrm{cfu} / \mathrm{yr}$ loadings per failing septic, ${ }^{\dagger}$ and if the number of septic system

261 connections identified in the TMDL were implemented, loadings could be reduced by $4.22 \mathrm{x}$

$26210^{15}$, which is $19 \%$ of the fecal coliform loadings from other urban non-point sources in the

263 Potomac River basin or 1\% of total loadings from all natural and anthropogenic sources.

264 The estimated reductions in loads would be a substantial fraction of total loads to either

265 the Potomac River or Chesapeake Bay watersheds. However, percentage reductions could be

266 much higher in small water bodies. Because pathogen loads tend to become concentrated in

267 localized areas, these reductions could be significant in terms of improving local water safety

268 and preventing beach or shellfish closures, if practices were implemented at sufficient levels

269 within small basins.

271 Potential Magnitude of Benefits

272 Whether reductions in pathogens reduce human illness from water contact or shellfish

273 ingestion is a function of the ability of the pathogens to produce disease in people, probability of

274 exposure to the pathogens, pathogen concentration, the number of people exposed, and the

$\dagger$ Several estimates of fecal coliform loadings per failing septic units were identified within the Chesapeake Bay Watershed during the literature review. The range per unit was $4.47 \times 10^{9}$ to $6.39 \times 10^{12} \mathrm{cfu} / \mathrm{yr}$. The median range was selected for this estimate because it was based on Hydrological Simulation Program - Fortran (HSPF) modeling of instream loadings rather than per capita fecal coliform production rate Virginia Department of Environmental Quality. (2003). "Total maximum daily load development for Linville Creek: bacteria and general standard (benthic) impairments. Page 160." from http://www.deq.virginia.gov/portals/0/DEQ/Water/TMDL/apptmdls/shenrvr/linville.pdf, Virginia Department of Environmental Quality. (2011). "Bacteria TMDL development for the tributaries to the Potomac River: Sugarland Run, Mine Run, and Pimmit Run. Page 103." from http://www.deq.virginia.gov/portals/0/DEQ/Water/TMDL/drftmdls/sugarland.pdf, West Virginia Department of Environmental Protection. (2012). "West Virginia's nonpoint source program 2011 annual report." from http://www.epa.gov/reg3wapd/pdf/pdf_nps/nps_annualreports/2011/WV\%202011\%20NPS\% 20AR.pdf. 
275 characteristics of the people that influence their susceptibility to disease (e.g., Soller, Olivieri et

276 al. 2003). A quantification of all these effects was beyond the scope of this project. However, we

277 gathered some existing information and data to suggest the potential order of magnitude of

278 benefits.

279 FIB are correlated with a number of illnesses caused by bacteria and viruses, and the

280 illness that has been most consistently and clearly linked to water contact is increased risk of

281 gastroenteritis (Kay, Fleisher et al. 1994, Fleisher, Kay et al. 1998, Wade, Sams et al. 2010),

282 although other diseases have also been observed, including respiratory illnesses, ear infections,

283 and skin rashes (Fleisher, Kay et al. 1998, Fleisher, Fleming et al. 2010). Skin diseases

284 (infections and rashes) have been most closely linked to non-point sources of pathogens

285 (Fleisher, Fleming et al. 2010), whereas gastroenteritis is more clearly linked to sewage (Wade,

286 Sams et al. 2010). The gastrointestinal illnesses caused by shellfish consumption have been

287 linked to concentrations of Vibrio spp. (Hlady and Klontz 1996), but Vibrio concentrations are

288 widespread in the marine environment and are not highly correlated with fecal coliform

289 (DePaola, Kaysner et al. 2000) and only weakly correlated with nitrogen concentrations (Pfeffer,

290 Hite et al. 2003, Eiler, Johansson et al. 2006, Johnson, Flowers et al. 2010). However,

291 concentrations of Vibrio spp. have been linked to increased sediment suspension in some cases

292 (Vanoy, Tamplin et al. 1992, Pfeffer, Hite et al. 2003, Fries, Characklis et al. 2008).

293 The number of people harmed is indicated by the cases of reported illness that can be

294 linked to waterborne pathogens. Table 5 presents reported illnesses from Maryland and Virginia.

295 These states were included because these are the states with Chesapeake Bay shoreline, but other

296 swimmable water bodies would also be affected by pathogens. 
297 Table 5. Reported Diseases due to Pathogens in Water Bodies in Maryland and Virginia

298 (2004-2013) $)^{\mathbf{a}}$.

\begin{tabular}{|l|l|l|}
\hline \multicolumn{1}{|c|}{ Waterborne Disease } & Maryland Average & Virginia Average \\
\hline Cryptosporidiosis & 48 & 101 \\
\hline Giardiasis & 261 & 137 \\
\hline Listeriosis & 17 & 455 \\
\hline Shiga: toxin producing E. coli (STEC) & 96 & 19 \\
\hline Shigellosis & 164 & 159 \\
\hline Vibriosis & 35 & 32 \\
\hline Total & $\mathbf{6 2 1}$ & $\mathbf{9 0 2}$ \\
\hline
\end{tabular}

299

300

301

302

303

304

305

306

307

308

309

310

311

312

313

314

315

316

317

a Totals include illnesses due to treated (e.g., pools) and untreated (e.g., estuaries) water bodies, although the majority of these illnesses are likely from treated water bodies, which would not be affected by BMP implementation.

Source data: (VDH 2014) and (Maryland Department of Health and Mental Hygiene 2013, December 19).

These data on illnesses suggest a potential order of magnitude of illnesses caused by pathogens, but are not an accurate accounting, for three reasons. First, these numbers may be underestimates of true disease incidence due to water contact because only a fraction of illnesses are likely to have been identified and reported. Many more cases of gastrointestinal illnesses are likely to occur than to be reported (Hlavsa, Roberts et al. 2014). Further, anecdotal information suggests that skin rashes and infections due to water contact are not an uncommon ailment in the Chesapeake Bay (Kobell 2011, Kobell 2013), particularly in the warmest months. These cases are not usually reported but have been documented elsewhere (Wade, Sams et al. 2010). Second, this particular set of cases may not be representative of risk associated with swimming in the Chesapeake Bay or its tributaries. Data collected by the Centers for Disease Control and Prevention using different reporting criteria found that $70 \%$ of reported illnesses due to waterborne pathogens were from pools or other treated water and $30 \%$ were from open (untreated) water, such as lakes and oceans (Hlavsa, Roberts et al. 2014). Third, the relationship 
318 between animal-derived pathogens and human illnesses is poorly understood. Many dose-

319 response relationships are based on pathogens from sewage sources, not agricultural sources.

320 Because of these data limitations, an estimation of the reduction in cases of disease was

321 beyond the scope of this effort. However, we know that at least some water bodies contain

322 dangerous levels of pathogen concentrations (evidence provided by TMDLs and cases of

323 disease) that will be reduced in different proportions depending on the extent of BMP

324 implementation in the watershed. The ability to reduce areas of high pathogen concentrations in

325 areas with a high probability of exposure will have the most potential to create benefits.

\section{Potential Value of Reduction in Pathogens}

This analysis suggests that these reductions can provide the following benefits to people

328 in the Chesapeake Bay watershed. First, those who are in contact with the water (commercial

329 fishermen, recreational anglers, boaters, and swimmers) are likely to have improved welfare due

330 to illnesses avoided and may increase the number of trips they take. Second, more risk-averse

331 recreators, who might currently avoid the water, might be induced to recreate in the Chesapeake

332 Bay, in response to improved water safety (Lipton 2004). Third, increased safety of shellfish

333 could benefit commercial watermen, the burgeoning aquaculture industry, and seafood

334 consumers. We would expect welfare increases from additional recreation trips, increased safety

335 per trip, lowered costs of production for producers, and safer shellfish for consumers.

336 Table 6 summarizes the potential values of avoiding illnesses and beach closures as

337 identified in the economic literature.

338 Table 6. Summary of Economic Values Identified in the Literature.

\begin{tabular}{|c|c|c|}
\hline Value Pathway (per Person) & $\begin{array}{c}\text { Economic Value } \\
\text { Estimate }\end{array}$ & \multicolumn{1}{|c|}{ Reference } \\
\hline Willingness to pay to avoid illness & $\$ 20.70-\$ 64.43$ & $\begin{array}{l}\text { Machado and Mourato } \\
\text { (Machado and Mourato 2002) }\end{array}$ \\
\hline
\end{tabular}




\begin{tabular}{|l|l|l|}
\hline Loss of beach trips & $\$ 2.51-\$ 19.71$ & $\begin{array}{l}\text { McConnell and Tseng } \\
\text { (McConnell and Tseng 1999) }\end{array}$ \\
\hline Value of beach closure & $\$ 4.35-\$ 7.96$ & $\begin{array}{l}\text { McConnell and Tseng } \\
\text { (McConnell and Tseng 1999) }\end{array}$ \\
\hline Value of beach closure & $\$ 0.00-\$ 24.46$ & $\begin{array}{l}\text { Parsons et al. (Parsons, Massey } \\
\text { et al. 1999) }\end{array}$ \\
\hline Loss of beach trips & $\$ 40.02$ & $\begin{array}{l}\text { Murray et al. (Murray, Sohngen } \\
\text { et al. 2001) }\end{array}$ \\
\hline
\end{tabular}

Given the potential number of beach users in the Chesapeake Bay $\$$, the total economic

341 value of pathogen reductions due to the TMDL could be substantial when aggregated over the

342 total number of beach users. Virginia had 29 days of beach actions (notifications and closure

343 days) out of a total of 6,900 beach days in 2012 (open days multiplied by number of beaches),

344 and an average of 56 beach actions per year from 2007-2012 (VDH 2014; (EPA). Maryland had

345139 days of beach actions out of a total 6,501 beach days in 2012, and an average of 196 beach

346 actions per year from 2007-2012 (EPA 2013).

347 Furthermore, these estimates do not include avoided costs due to reduced shellfish bed

348 closures, lost wages and medical bills due to illness, or costs associated with stream miles

349 impaired due to pathogens. Over 9,000 stream miles in Virginia EPA (2013), over 4,000 miles in

350 Maryland (MDE 2012), and 190 miles in Pennsylvania (EPA 2013) are impaired for E. coli and

351 fecal coliform. $\S$ A reduction in impaired stream miles would decrease both administrative costs

352 associated with listing impaired waters and costs associated with developing and implementing

353 TMDLs as required by Clean Water Act Section 303(d) (EPA 2015, December 15).

\$ The number of people swimming in Chesapeake Bay was not readily available but a survey estimates that $42 \%$ of US residents engage in swimming in lakes, ponds, oceans, or rivers in a given year Cordell, H. K., G. T. Green, V. R. Leeworthy, R. Stephens, M. J. Fly and C. J. Betz. (2005). "United States of America: outdoor recreation. Pages 245-264." Retrieved November 26, 2014, from http://www.treesearch.fs.fed.us.proxyum.researchport.umd.edu/pubs/21302..

$\S$ The watershed also includes the District of Columbia and portions of West Virginia, Delaware, and New York. 
Future efforts to estimate the total economic value of the TMDL with respect to pathogen

355 reductions are required to fully understand the potential of the action.

\section{Conclusions}

Our literature review revealed that many BMPs being installed to reduce nutrients are

effective at reducing pathogens. We provide a rough estimate of a $19 \%$ reduction in loads to tidal waters of the Potomac River and a $27 \%$ reduction in loads to tidal waters of the Chesapeake Bay.

Substantial new modeling and data collection would be required to improve this estimate and

361 relate it to reduced cases of illness, beach closures, or shellfish bed closures. If we take the

362 simple approach of assuming that adverse events decline at the same rate as pathogen

363 concentrations in the Chesapeake Bay (27\%), we estimate that this would translate to hundreds

364 of fewer cases of reported illness and substantial welfare effects. The health benefits of a $27 \%$

365 reduction appear modest based on overall reported numbers of illnesses. However, benefits could

366 be significant for a local area if BMPs were concentrated in a watershed with a combination of

367 moderate pathogen concentrations and a resource heavily used for recreation or shellfishing.

368 This study also suggests that there are additional benefits of the TMDL that have not

369 been fully investigated and are not currently valued. Additional investigations are critical to

370 helping decision makers understand the full suite of benefits that may be realized through the

371 implementation of the TMDL as well as other water management and 303(d) actions.

\section{Acknowledgments}

The authors thank Jeff Sweeney, Brenda Rashleigh, Naomi Detenbeck, George van

374 Houtven and Ross Loomis for helpful data, discussions and comments in the development of this 375 paper. 


\section{References}

378 Byers, H. L., M. L. Cabrera, M. K. Matthews, D. H. Franklin, J. G. Andrae, D. E. Radcliffe, M.

379 A. McCann, H. A. Kuykendall, C. S. Hoveland and V. H. Calvert, 2nd (2005). "Phosphorus,

380 sediment, and Escherichia coli loads in unfenced streams of the Georgia Piedmont, USA." J

381 Environ Qual 34(6): 2293-2300.

382 City of Grand Rapids. (2011). "What are combined sewers?" Retrieved January 11, 2013, from

383 http://grcity.us/enterprise-services/Environment-Services/Pages/Combined-Sewer-

384 Overflow.aspx.

385 Clary, J., J. Jones, B. Urbonas, M. Quigley, E. Strecker and T. Wagner (2008). "Can stormwater

386 BMPs remove bacteria? New findings from the International Stormwater BMP Database."

387 Stormwater Magazine 9: 14.

388 Cordell, H. K., G. T. Green, V. R. Leeworthy, R. Stephens, M. J. Fly and C. J. Betz. (2005).

389 "United States of America: outdoor recreation. Pages 245-264." Retrieved November 26, 2014,

390 from http://www.treesearch.fs.fed.us.proxy-um.researchport.umd.edu/pubs/21302.

391 DePaola, A., C. A. Kaysner, J. Bowers and D. W. Cook (2000). "Environmental investigations of

392 Vibrio parahaemolyticus in oysters after outbreaks in Washington, Texas, and New York (1997

393 and 1998)." Appl Environ Microbiol 66(11): 4649-4654.

394 Eiler, A., M. Johansson and S. Bertilsson (2006). "Environmental influences on Vibrio

395 populations in northern temperate and boreal coastal waters (Baltic and Skagerrak Seas)." Appl

396 Environ Microbiol 72(9): 6004-6011.

397 EPA. (2012). "Recreational water quality criteria." from

398 https:/www.epa.gov/sites/production/files/2015-10/documents/rwqc2012.pdf.

399 EPA. (2012, August). "Virginia 2011 swimming season update." from

400 http://water.epa.gov/type/oceb/beaches/2011va.cfm.

401 EPA. (2013). "EPA's beach report: Maryland 2012 swimming season." from

402 http://www2.epa.gov/sites/production/files/2013-09/documents/md2012.pdf.

403 EPA. (2013). "EPA's BEACH report: Virginia 2012 swimming season." from

404 http://www2.epa.gov/sites/production/files/2013-10/documents/va2012.pdf.

405 EPA. (2013, February 11). "Virginia assessment data for 2010." from

406 http://ofmpub.epa.gov/tmdl_waters10/attains state.control?p state=VA\&p_cycle=2010\&p repo

407 rt type $=\mathrm{A}$.

408 EPA. (2015, December 15). "Impaired waters and TMDLs program overview: introduction."

409 from https://www.epa.gov/tmdl/impaired-waters-and-tmdls-program-overview-introduction.

410 Fleisher, J. M., L. E. Fleming, H. M. Solo-Gabriele, J. K. Kish, C. D. Sinigalliano, L. Plano, S.

411 M. Elmir, J. D. Wang, K. Withum, T. Shibata, M. L. Gidley, A. Abdelzaher, G. He, C. Ortega,

412 X. Zhu, M. Wright, J. Hollenbeck and L. C. Backer (2010). "The BEACHES Study: health

413 effects and exposures from non-point source microbial contaminants in subtropical recreational

414 marine waters." Int J Epidemiol 39(5): 1291-1298.

415 Fleisher, J. M., D. Kay, M. D. Wyer and A. F. Godfree (1998). "Estimates of the severity of

416 illnesses associated with bathing in marine recreational waters contaminated with domestic

417 sewage." Int J Epidemiol 27(4): 722-726.

418 Fries, J. S., G. W. Characklis and R. T. Noble (2008). "Sediment-water exchange of Vibrio sp.

419 and fecal indicator bacteria: implications for persistence and transport in the Neuse River

420 Estuary, North Carolina, USA." Water Res 42(4-5): 941-950. 
421 Hlady, W. G. and K. C. Klontz (1996). "The epidemiology of Vibrio infections in Florida, 1981422 1993." J Infect Dis 173(5): 1176-1183.

423 Hlavsa, M. C., V. A. Roberts, A. M. Kahler, E. D. Hilborn, T. J. Wade, L. C. Backer and J. S. 424 Yoder. (2014). "Recreational water-associated disease outbreaks_-United States, 2009-2010." 425 from http://www.cdc.gov/mmwr/preview/mmwrhtml/mm6301a2.htm.

426 Johnson, C. N., A. R. Flowers, N. F. Noriea, 3rd, A. M. Zimmerman, J. C. Bowers, A. DePaola 427 and D. J. Grimes (2010). "Relationships between environmental factors and pathogenic Vibrios 428 in the Northern Gulf of Mexico." Appl Environ Microbiol 76(21): 7076-7084.

429 Kay, D., J. M. Fleisher, R. L. Salmon, F. Jones, M. D. Wyer, A. F. Godfree, Z. Zelenauch-

430 Jacquotte and R. Shore (1994). "Predicting likelihood of gastroenteritis from sea bathing: results 431 from randomised exposure." Lancet 344(8927): 905-909.

432 Knox, A. K., R. A. Dahlgren, K. W. Tate and E. R. Atwill (2008). "Efficacy of natural wetlands 433 to retain nutrient, sediment and microbial pollutants." J Environ Qual 37(5): 1837-1846. 434 Kobell, R. (2011, June). "Health officials struggle with how to react to Vibrio cases." from 435 http://www.bayjournal.com/article/health_officials_struggle_with_how to react to vibrio case 436 s.

437 Kobell, R. (2013, July 4). "To be safe, surf the Internet before swimming at the beach:

438 Monitoring programs finding dangerous levels of bacteria in Bay and many of its rivers."

439 Retrieved November 23, 2014, from

440 http://www.bayjournal.com/article/to_be_safe_surf the internet_before_swimming_at_the_beac 441 h.

442 Leisenring, M., J. Clary and P. Hobson. (2012). "Pollutant category summary statistical 443 addendum: TSS, bacteria, nutrients, and metals. Page 31. Addendum, International Stormwater 444 BMP Database." from

445 http://www.bmpdatabase.org/Docs/2012\%20Water\%20Quality\%20Analysis\%20Addendum/BM 446 P\%20Database\%20Categorical_SummaryAddendumReport_Final.pdf.

447 Lipton, D. W. (2004). "The value of improved water quality to Chesapeake Bay boaters. Marine 448 Resource Economics 19." from http://ideas.repec.org/a/ags/mareec/28116.html.

449 Machado, F. S. and S. Mourato (2002). "Evaluating the multiple benefits of marine water quality 450 improvements: how important are health risk reductions?" J Environ Manage 65(3): 239-250.

451 Mallin, M. A., K. E. Williams, E. C. Esham and R. P. Lowe (2000). "Effect of human

452 development on bacteriological water quality in coastal watersheds." Ecological Applications 10: 453 1047-1056.

454 Marion, J. W., J. Lee, S. Lemeshow and T. J. Buckley (2010). "Association of gastrointestinal 455 illness and recreational water exposure at an inland U.S. beach." Water Res 44(16): 4796-4804.

456 McConnell, K. E. and W.-C. Tseng (1999). "Some preliminary evidence on sampling of 457 alternatives with the random parameters logit." Marine Resource Economics 14: 317-332.

458 MDE. (2012). "Maryland's final 2012 integrated report of surface water quality. Table 31." from 459 http://www.mde.maryland.gov/programs/Water/TMDL/Integrated303dReports/Documents/Integ 460 rated_Report_Section_PDFs/IR_2012/MD_Final_2012_IR_Parts_A-E.pdf.

461 MDE. (2016). "Detailed descriptions of MDE's shellfish growing water classifications as of 462 2016." from

463 http://www.mde.state.md.us/programs/Marylander/CitizensInfoCenterHome/Documents/www.m 464 
465 Maryland Department of Health and Mental Hygiene (2013, December 19). "Cases of selected

466 notifiable conditions reported in Maryland." Retrieved September 23, 2014, from

467 http://phpa.dhmh.maryland.gov/SitePages/disease-conditions-count-rates.aspx.

468 Minnesota Pollution Control Agency. (2009). "Groundhouse river fecal coliform and biota

469 (sediment) total maximum daily load implementation plan. Page 61." from

470 http://www.pca.state.mn.us/index.php/view-document.html?gid=7922.

471 Murray, C., B. Sohngen and L. Pendleton (2001). "Valuing water quality advisories and beach

472 amenities in the Great Lakes." Water Resources Research 37: 2583-2590.

473 Parsons, G. R., D. M. Massey and T. Tomasi (1999). "Familiar and favorite sites in a random

474 utility model of beach recreation." Marine Resource Economics 14: 299-315.

475 Pelton, T. and B. Goldsborough. (2010, July). "On the brink: Chesapeake's native oysters: what

476 it will take to bring them back." from http://www.cbf.org/document.doc?id=523.

477 Petersen, C. M., H. S. Rifai and R. Stein (2009). "Bacteria load estimator spreadsheet tool for

478 modeling spatial Escherichia coli loads to an Urban Bayou." Journal of Environmental

479 Engineering 135: 203-217.

480 Peterson, J., C. Cavinder, K. Wagner and L. Redmon. (2012). "Lone Star healthy streams: horse 481 manual. Page 67." from http://1shs.tamu.edu/media/340453/horse manual.pdf.

482 Peterson, J., E. Jordan, K. Wagner and L. Redmon. (2012). "Lone Star healthy streams: dairy

483 cattle manual. Page 80." from http://shs.tamu.edu/media/340447/dairy manual.pdf.

484 Peterson, J., L. Redmon and M. McFarland. (2011). "Reducing bacteria with best management

485 practices for livestock: access control. Page 2." from http://shs.tamu.edu/media/340523/esp-

486409 access_control.pdf.

487 Peterson, J., L. Redmon and M. McFarland. (2011). "Reducing bacteria with best management

488 practices for livestock: prescribed grazing. Page 2." from http://lshs.tamu.edu/media/340541/esp-

489415 prescribed grazing.pdf.

490 Pfeffer, C. S., M. F. Hite and J. D. Oliver (2003). "Ecology of Vibrio vulnificus in estuarine

491 waters of eastern North Carolina." Appl Environ Microbiol 69(6): 3526-3531.

492 Ramirez, N. E., P. Wang, J. Lejeune, M. J. Shipitalo, L. A. Ward, S. Sreevatsan and W. A. Dick

493 (2009). "Effect of tillage and rainfall on transport of manure-applied Cryptosporidium parvum

494 oocysts through soil." J Environ Qual 38(6): 2394-2401.

495 Redmon, L., K. Wagner and J. Peterson. (2012). "Lone Star healthy streams: beef cattle manual.

496 Page 70." from http://lshs.tamu.edu/media/340444/beef cattle.pdf.

497 Savichtcheva, O. and S. Okabe (2006). "Alternative indicators of fecal pollution: relations with

498 pathogens and conventional indicators, current methodologies for direct pathogen monitoring

499 and future application perspectives." Water Res 40(13): 2463-2476.

500 Schaetzle, H. L. (2005, July 28). "Water quality assessment of a degraded stream prior to

501 restoration and nitrate reduction through controlled drainage." Retrieved December 17, 2012,

502 from http://www.lib.ncsu.edu/resolver/1840.16/117.

503 Sheffield, R., S. Mostaghimi, D. H. Vaughan, E. R. J. Collins and V. G. Allen (1997). "Off-

504 stream water sources for grazing cattle as a stream bank stabilization and water quality BMP."

505 Transactions of the ASAE 40: 595-604.

506 Soller, J. A., A. W. Olivieri, J. Crook, R. C. Cooper, G. Tchobanoglous, R. T. Parkin, R. C.

507 Spear and J. N. S. Eisenberg (2003). "Risk-based approach to evaluate the public health benefit

508 of additional wastewater treatment." Environmental Science \& Technology 37: 1882-1891. 
509 Tilman, L., A. Plevan and P. Conrad. (2011). "Effectiveness of best management practices for

510 bacteria removal: developed for the upper Mississippi River bacteria TMDL. Page 18." from

511 http://www.pca.state.mn.us/index.php/view-document.html?gid=16328.

512 Vann, D. T., R. Mandel, J. M. Miller, E. Hagen, A. Buda and D. Cordalis. (2002). "The District

513 of Columbia source water assessment. Pages 6.1-6.40." from

514 http://www.potomacriver.org/2012/drinkingwaterdocs/deswap/.

515 Vanoy, R. W., M. L. Tamplin and J. R. Schwarz (1992). "Ecology of Vibrio vulnificus in

516 Galveston Bay oysters, suspended particulate matter, sediment and seawater: detection by

517 monoclonal antibody - immunoassay — most probable number procedures." Journal of

518 Industrial Microbiology 9: 219-223.

519 Virginia Department of Environmental Quality. (2003). "Total maximum daily load development

520 for Linville Creek: bacteria and general standard (benthic) impairments. Page 160." from

521 http://www.deq.virginia.gov/portals/0/DEQ/Water/TMDL/apptmdls/shenrvr/linville.pdf.

522 Virginia Department of Environmental Quality. (2011). "Bacteria TMDL development for the

523 tributaries to the Potomac River: Sugarland Run, Mine Run, and Pimmit Run. Page 103." from

524 http://www.deq.virginia.gov/portals/0/DEQ/Water/TMDL/drftmdls/sugarland.pdf.

525 VDH. (2012). "Shellfish closure and shoreline survey documents." from

526 http://www.vdh.state.va.us/EnvironmentalHealth/Shellfish/closureSurvey/index.htm.

527 VDH. (2014). "Reportable disease surveillance in Virginia, 2012." from

528 http://www.vdh.virginia.gov/Epidemiology/Surveillance/SurveillanceData/ReportableDisease/Ta

529 bles/table6 region12.pdf.

530 Wade, T. J., E. Sams, K. P. Brenner, R. Haugland, E. Chern, M. Beach, L. Wymer, C. C. Rankin,

531 D. Love and Q. Li (2010). "Rapidly measured indicators of recreational water quality and

532 swimming-associated illness at marine beaches: a prospective cohort study." Environmental

533 Health 9: 1-14.

534 West Virginia Department of Environmental Protection. (2012). "West Virginia's nonpoint

535 source program 2011 annual report." from

536 http://www.epa.gov/reg3wapd/pdf/pdf_nps/nps_annualreports/2011/WV\%202011\%20NPS\%20

537 AR.pdf.

538 Zarriello, P. J., R. F. Breault and P. K. Weiskel. (2003). "Potential effects of structural controls

539 and street sweeping on stormwater loads to the lower Charles River, Massachusetts. Page 48."

540 from http://pubs.usgs.gov/wri/wri024220/pdfs/wrir024220.pdf. 